\title{
The Necessity of Redefining and Presenting a New Perception on the Comprehensive Interpretation of the Holy Quran
}

\section{La necesidad de redefinir y presentar una nueva percepción sobre la interpretación integral del Sagrado Corán}

Saeed Ghazipour
Ph.D. Student, Department of Theology, Shahr-e-Rey Branch, Islamic Azad University, Tehran, Iran

ORCID: https://orcid.org/0000-0003-1475-069X

\section{Mohammad Reza Shirazi $(D)$}

Department of Theology, Shahr-e-Rey Branch, Islamic Azad University, Tehran, Iran ORCID: https://orcid.org/0000-0003-1262-0218

Seyedeh Fatemeh Hosseini Mirsafi

Department of Theology, Shahr-e-Rey Branch, Islamic Azad University, Tehran, Iran ORCID: https://orcid.org/0000-0001-5668-0250

*Correspondence

Email: shirazi.mr@gmail.com
Cite as:

Ghazipour, S., Shirazi, M.R., \& Hosseini Mirsafi, S.F. (2021). The Necessity of Redefining and Presenting a New Perception on the Comprehensive Interpretation of the Holy Quran. Propósitos y Representaciones, 9 (SPE2), e966. Doi: http://dx.doi.org.10.20511.pyr2021.v9nSPE2.966 


\section{Summary}

The Holy Quran is an infinite ocean which benefits everyone to the extent of their scientific ability and scope of existence. This divine book would not be only a text; rather, its interpretation and explanation open various chapters of science, wisdom, and knowledge to human beings. Therefore, the only way to enter this gate of science, wisdom, and knowledge is its interpretation. Up to now, various approaches and interpretive books have been emerged to decipher and decode this divine blessing, but non of them has been perfect, and each is considered as a defect. Therefore, the best and the safest way would be to refer to a new definition of the "comprehensive" interpretation. In the following research paper, we will try to express the need and necessity of applying a comprehensive approach to the interpretation of the Holy Quran, providing a new definition of it in the description of the divine words.

Keywords: the nature of the Holy Quran; the interpretive approaches; the interpretive interpretation

\section{Resumen}

El Sagrado Corán es un océano infinito que beneficia a todos en la medida de su capacidad científica y alcance de existencia. Este libro divino no sería solo un texto; más bien, su interpretación y explicación abre varios capítulos de ciencia, sabiduría y conocimiento a los seres humanos. Por lo tanto, la única forma de entrar por esta puerta de la ciencia, la sabiduría y el conocimiento es su interpretación. Hasta ahora han surgido diversos enfoques y libros interpretativos para descifrar y decodificar esta bendición divina, pero ninguno de ellos ha sido perfecto, y cada uno se considera un defecto. Por lo tanto, la mejor y más segura forma sería referirse a una nueva definición de la interpretación "integral". En el siguiente trabajo de investigación, intentaremos expresar la necesidad y necesidad de aplicar un enfoque integral a la interpretación del Sagrado Corán, proporcionando una nueva definición del mismo en la descripción de las palabras divinas.

Palabras clave: la naturaleza del Sagrado Corán; los enfoques interpretativos; la interpretación interpretativa

\section{Introduction}

The Holy Quran includes the divine words, which has been sent from on high to the prophet of Islam, His Holiness Muhammed (Peace Be Upon Him and His Family). This holy book encompasses one - hundred and fourteen suras, and six - thousand, two - hundred and thirty-six verses (Majlessi, 1403 A.D.). Besides its undivided and repelling force coming down from on high, which have been specified in Quranic verses and Islamic hadiths themselves, the Holy Quran, in spite of the objection of the pagans of the time, who would say that why the [Holy] Quran has not come down step by step or so to speak "astronomically" from on high to the prophet of Islam within twenty or twenty - three years, it came down from on high step by step. Along with all the incidents happened in the beginning of Islam, the Holy Quran has been sent from on high to answer all human needs. Having been come down from on high, Quranic suras and verses would be put into writing on the request of the prophet of Islam; and Muslims of the time made great efforts to put this divine message into writing In addition to making great efforts to put it into writing, the early Muslims would embark on memorizing and learning its teachings as well. Before long, thousands of Muslims embarked on memorizing and transmitting this divine book (Zarkashi, 1411 A.D.). In it inner contents, the Holy Quran does illustrate the primordial emergence of most sciences needed for human beings (Tourani, 2010). 
As a sublime text, some of the Holy Quran's characteristics would require us to interpret it for a better understanding. For instance, in addition to Quranic verses which deal with the visible world, there are Quranic verses which speak of the truths beyond this visible world. This will make these Quranic verses difficult to understand. Or through few words and phrases, it would present all the cultures needed for human beings in order to be happy and fortunate in this world. For this reason, some of Quranic verses do require more attention and contemplation. Therefore, it would be necessary that these Quranic verses be interpreted (Tourani, 2010). Beyond its superficial introduction, the Holy Quran does have another truth and nature, the truth and nature which are very difficult to access, hence to speak about them, too, would be difficult (Nassiri, 2009). Any thinker, having little knowledge about the Holy Quran, is well aware that the cultures and bodies of knowledge hidden in the words and phrases of the Holy Quran do enjoy different and various levels and degrees, knowing that the significations of Quranic verses on those cultures and bodies of knowledge would not be the same. The understanding of these cultures and bodies of knowledge for every person who knows the Arabic language would be possible without the Quranic verses to be interpreted; such a person, on the basis of his or her knowledge, may gain the guidance of these Quranic verses, but understanding the most parts of the cultures and bodies of knowledge of this great book, which are beyond the understanding of the public, in spite of their knowing the Arabic language, their understanding of the Quranic verses without referring to Quranic interpretations would not be possible. At all. From the beginning years of the religion of Islam up to now, great efforts have been made by Islamic scholars for interpreting the Holy Quran, and numerous interpretive books on the whole Holy Quran or parts of it have been put into writing (Muhammadi yadak, 2011). Each Quranic interpreter has chosen his or her own favorite way of interpreting the Holy Quran, and each of these Quranic interpreters has written interpretive books based on their own cultures and the conventions ruling over their society.

In some of these Quranic interpretations, the major message of God, the Almighty has been lost among the interpreter's thoughts and presuppositions (Hashemian Fard, 2008). But what has been the real secret of the endless desire of hundreds of thinkers who have devoted all or parts of their precious life to understand, define, and interpret the teachings and cultures of the Holy Quran? Except the Holy Quran, is there a book in the world, on which, insiders and outsiders have put their thoughts into writing? What is the secret of all this bewilderment on the part of thinkers and charm on the part of the Holy Quran? How can this much of love, fascination, and enchantment be expressed and interpreted?

\section{Expressing the Question}

Not only is the Holy Quran considered as the essential source for human knowledge to guide human beings in this world, but also it is regarded as a means and a medium to transmit its essential knowledge to the hearts of human beings (Nosrat, 2017). There is a great pleasure and joy in reading the Holy Quran and listening to its pleasant voice. As a matter of fact, the Holy Quran has in its depths encompassed rare jewels and gems, in which the able divers, with their contemplations and deep thoughts may dive into the sea of it, opening its seashells, extracting precious jewels. As it has been said in an Islamic hadith: "There are [precious] phrases, allusions, and delicate sentences, and truth in the Holy Quran" (Sho'airi, 1984). The Holy Quran's [precious] phrases are for common people; its [precious] allusions are for the chosen; its delicate, [precious] sentences are for the holy chosen; its delicate, [precious] sentences are for the holy people; and its [precious] truths are for the [divine] prophets. In order to gain this divine source of knowledge more and more, and in order to heal the individual as well as the social pains through this divine pharmacy, and in order to make one's soul and spirit purer and purer, one has to learn how to understand the divine messages of the Holy Quran. The Holy Quran speaks through a human language; therefore, if one knows the Arabic language, he or she will understand the Holy Quran's divine messages to some extent, but, having some special characteristics such as the inner meanings of the Quranic verses, a wide breadth of cultures and bodies of knowledge, and, most importantly, its all - inclusive perspective, it requires more 
contemplations, deliberations, and interpretations by the Islamic scholars (Karimi, 2003). In literal meaning, the Arabic word "تفسير" (=interpretation) originates from the Arabic root of the word "فرر" (Fasara), meaning "finding out", "expressing", and "clarifying" the difficult words and phrases. The science of interpretation, the science of understanding and knowing the Holy Quran, and expressing the meaning as well as extracting the Holy Quran's religious orders and cultures with respect to the significations of Quranic verses on Allah, are all considered as interpreting, decoding, and deciphering the difficult words and phrases of the Holy Quran. The word "تفسير" (= interpretation), with the same meaning mentioned above, has been used only once in the Holy Quran, that is to say, in the sura of "Forqan", verse thirty - three. This word, that is to say, the word "تقسبر" (=interpretation), has been mentioned in the book "Nahjol Blaqah" with the meaning of interpreting the Holy Quran in sermon number one - hundred and fifty. But, one of the important issues in interpreting the Holy Quran as well as in interpretive books on the Holy Quran are the interpretive approaches and methods based on which an interpreter would embark on interpreting the Holy Quran (Shari'ati Niasar, 2016). The history reveals that early Muslims, in spite of their enjoyment of linguistic eloquence and being fluent in the Arabic language, had been unable to understand the Quranic verses. For this reason and for other reasons mentioned before, the interpretation of the Holy Quran do have a great place in the history of Islam. Although the Shiite innocent imams (Peace Be Upon them) made great efforts to present a more correct meaning of the Quranic verses, they had not been dealt with as they should have been (Reza'ee, 2019). Referring to the interpretive books on the Holy Quran, it will be understood that none of them has had the factor of "comprehensiveness" as required. Why, because all of those Quranic interpretations have dealt with the divine message from a single specific point of view. Therefore, a question is raised here, "which source has to be referred to in order to find an all - inclusive approach, an approach which is beyond the interpreter's one - track mindedness?" In order to answer this important question, we will look at the "comprehensive" approach to the interpretation of the Holy Quran as the only and the safest way to interpret the Holy Quran.

\section{The Types of Interpretive Approaches}

According to a general division, which is based on "the approach", interpretations of the Holy Quran are divided into six types: 1) "the Quran - by Quran" approach, in which the Holy Quran is interpreted on the basis of the Quran itself; 2) the "hadith" approach, in which the Holy Quran is interpreted on the basis of the narrative record of the sayings or customs of the prophet of Islam (Peace Be Upon Him) and his companions; this approach is also called "the narrating" approach; 3) "the rational" approach, in which the Holy Quran is interpreted on the basis of the rationale as well as the "Ijtehaad" (=extracting and comprehending the Quranic verses and Islamic questions from the Holy Qurans through habits, consensus, and the rationale); 4) "the revelatory" approach, in which the Holy Quran is interpreted by the revelations; in this approach, the interpreter raises his or her own inner abilities, and, thus, his or her comprehension of the Quranic Verses is increased; 5) "the scientific" approach, in which the Holy Quran is interpreted on the basis of existing sciences; this approach is also called "the experimental sciences" approach; 6) "the comprehensive" approach, in which the Holy Quran is interpreted by a combination of the five foregoing approaches; this approach has been paid less attention by the Islamic scholars than the other approaches mentioned above; as a matter of fact, this approach has remained discarded throughout the ages and centuries. Except the comprehensive approach, non of the other foregoing five approaches mentioned above do suffice in interpreting the Holy Quran. As a matter of fact, no comprehensive interpretation of the Holy Quran has up to this time presented or introduced by Islamic scholars. Why, because the Islamic scholars and interpreters have never enjoyed the mastery of sciences, cultures, and bodies of know ledge of the time in which they lived, so they had not been able to enter deeply and comprehensively the Quranic verses. Or it may be that the times, in which theses Islamic scholars and interpreters lived, did not allow them to become masters of sciences, cultures, and bodies of knowledge. and bodies of knowledge. Yet, the verses of the Holy Quran enjoy a surprising comprehensiveness, which are similar to "the talking Quran" and "the innocent 
imams". Since the blessings and bounties of God, the Almighty are endless, the degree of understanding the Holy Quran depends on the degree an interpreter has mastery of different sciences, cultures, and bodies of knowledge; for this reason, for a Quranic interpretation to be called comprehensive, the interpreter must have the mastery of different sciences, cultures, and cognitive and scientific sources. Therefore, the scientific view, and a full mastery of different sciences, along with a sound revelation, as well as having a correct mystical view, along with modern existing sciences such as sociology, mathematics, astrology and the like will cause to increase the interpreter's comprehension, and understanding of the Quranic verses, a Her obtaining such bodies of knowledge and disciplines, he or she will be able to introduce and present a comprehensive interpretation of the Holy Quran in the end. There are two dimensions in the interpretation of the Holy Quran: 1) the interpreter him or herself; 2) the enthusiasm which comes from the Holy Quran. Therefore, any interpreter of the Holy Quran must be first interested in the Holy Quran, and then, for the necessary revelation needed to interpret, he or she must detain his or her enthusiasm and desire from the Holy Quran. According to Islamic scholars, the types of Quranic interpretations based on approach means an interpretive trend which is based on the interpreter's preoccupation and inclination. These Quranic interpretive trends are divided into several types such as "the mystical interpretation", "the narrative interpretation", "the scientific interpretation", "the social interpretation" (as the contemporary interpretations), "the jurisprudential - theosophical interpretation", "the philosophical eloquent interpretation", "the educational - ethical interpretation", "the jihadist interpretation" and the like. If the preoccupation of the interpreter would be with ethical issues reflected in the Holy Quran, he or she chooses the mystical trend, writing and interpreting the Holy Quran's verses based on mysticism and ethics, which have emerged to create a better world for human beings. Apart from other approaches, the interpreter may have preoccupations with philosophy, mysticism, social, jurisprudential, theosophical, scientific, lexical, figurative, educational, jihadist issues and the like. These approaches which may be applied to the interpretation of the Holy Quran, that is to say, those approaches which the interpreter uses based on his or her own inner abilities are few such as "the revelatory" approach, which consists of the Holy Quran as well as the hadiths; "the rational" approach, which would be on the basis of sciences and experimental sciences; and "the intuitive" approach, which is based on the interpreter's intuition. Some Quranic interpreters believe that the Quranic verses are divided into two types; 1) those Quranic verses which are clear enough, and do not need to be interpreted (Mohkamaat); 2) those Quranic verses which are vaguely stated and, thus, are not clear enough, hence, they need to be interpreted (Motashaabehat). As for "mohkamaat", Islamic scholars do believe that they are clear enough, and no interpreter has the right to add something of his own to them, like Rashidoddin Meibodi who had written a decipherable interpretation of the Holy Quran. On the other hand, a Quranic interpreter named Mohyoddin ibn-e Arabi has written a mystical interpretation of the Holy Quran, which is believed to be an arbitrary interpretation of the Holy Quran. Mohyoddin ibn-e Arabi lived in the eighth century A.D. vet, if a Quranic interpreter limits him or herself to the revelatory approach, or if they merely interpret the Holy Quran, or if they make use of the Quran - by - Quran approach, or if they apply the narrating approach, this would not be a right thing, because the comprehensiveness of the Holy Quran necessitates that all the approaches should be applied together in interpreting the Quranic verses, and they should bear in mind that all the approaches should be applied to each Quranic verse, thus, complete interpretation is one that includes all Quranic verses; therefore, the comprehensive sieve interpretation of the Holy Quran would be a must. Late Imam Khomeini (Peace Be Upon Him) once said: "In comparison with any Quranic interpretation put into writing, the next Quranic interpretation which may be put into writing, would not suffice." Basically, the miracle of the Holy Quran necessitates that the more yon contemplate it, and the more you interpret it, you will find out that there will be more Quranic points to be interpreted; like an endless gold mine from which the more yon extract gold, there remains more gold to be extracted. But, as long as you do not interpret the Holy Quran, you will not gain anything of its influential teachings and cultures. You can only extract gold from a gold mine when all the necessary extracting equipments would be available to you; but, if you are without the necessary extracting equipments to extract gold from the gold mine; you can not at all extract gold from the gold 
mine; therefore, the only condition for the interpretation of the Holy Quran would be the comprehensiveness approach (Ghazipour, 2019).

\section{The Necessity of Interpreting the Holy Quran Comprehensively}

If we score the inconsiderable interpretations of the Holy Quran number one - hundred, and if the impact of these Quranic interpretations on the society is scored one - hundred, too, a comprehensive interpretation of the Holy Quran, and its impact on the society will be scored an infinite number. It is said that when the twelfth imam of Shiites, His Holiness Mahdi is going to re-appear again, a comprehensive interpretation of the Holy Quran, too, will be put into writing. So, the comprehensive interpretation of the Holy Quran is supposed to increase the power of understanding and comprehension of all people. So far, the Quranic interpretations introduced and presented in the world have not been put into writing in a comprehensive manner, but if, one day, a comprehensive interpretation of the Holy Quran is put into writing and presented for the use of people of the world, especially for the scholars, God, the Almighty will open the gate of the infinite interpretation to the interpreter who embarks on interpreting the Holy Quran in a comprehensive manner; then, all the verses in the Holy Quran will be related to one another, and all the descriptions and interpretations of Quranic verses will be related to the descriptions and interpretations of other Quranic verses. Why, because the Holy Quran is considered as the message of God, the Almighty, and it is an infinite divine book, just like the world of being, in which, any action on the part of a human being would be related to and will influence other human beings, hence the whole world of being will be involved. To cut a long story short, we must not consider the Holy Quran as only a text or book. The Holy Quran has got a special nature just like the other worldly entities' natures. As a matter of fact, the Holy Quran's existential nature would be independent of other existential natures existing in the world of being. The Holy Quran without considering its divine text would not exist. What values about this great divine book would be its truth and its nature? A translation of the Holy Quran will never have the value of its real nature. Therefore, it must be said to the people of the world to learn the Arabic language, and read the Holy Quran, just as Muslims' prayer cannot be said in Farsi or English language. To not ignore the text of the Holy Quran, when interpreting it, would be considered as one of the conditions of interpreting the Holy Quran in a comprehensive manner. There is no doubt that the text of the Holy Quran must come with its translation, or the text of the Holy Quran must come with both its translation and interpretation.

\section{The Process of Interpreting the Holy Quran in a Comprehensive Manner}

1. Since the truth of the Holy Quran is considered as a comprehensive one, its interpretation, too, has to be a comprehensive one. Therefore, to interpret the Holy Quran, it would be necessary that the interpreter interprets it in a comprehensive point of view.

2. Inspiration and revelation may create a new worldview for the Quranic interpreter, increasing the human understanding as well as the level of Quranic discussions. These factors have been presented in late Mortaza Motahari's worldview and Quranic discussions (Motahari, 1979). For a Quranic interpretation to be called "comprehensive", two factors must play roles: 1) when the Quranic interpreter has interpreted all the verses existing in the Holy Quran, like the interpretive book "Majma'ol Bayan". Or Khadje Abdullah Ansari's interpretation of the Holy Quran, in which the Holy Quran has been interpreted in a mystical manner, for, he has interpreted all the verses existing in the Holy Quran. Or Rashidoddin Meibodi's interpretation of the Holy Quran, in which all the Quranic verses have been interpreted in a mystical manner. 2) When the Quranic interpreter has interpreted the Holy Quran using a comprehensive approach. For instance, in Borhaan's interpretation, which is a narrative interpretation of the Holy Quran, the interpreter has not interpreted all the Quranic verses, but all those verses which have been interpreted, have been interpreted in a comprehensive manner. Mohyoddin ibn-e Arabi's interpretation includes all the verses existing in the Holy Quran, but it is not considered as comprehensive. Also, Ebrani's interpretation of the Holy Quran would not be considered as comprehensive; this Quranic interpretation is said to be kept in Strasbourg Museum in France. 
These Quranic interpretations have been put into writing from the interpreter's single preoccupation and view. But it should be remembered that the goal of the Holy Quran has not been sending its verses originating from only one point of view. Rather, there is a global, universal, and all - inclusive point of view in all the Quranic verses. Even all the Quranic verses which are difficult to understand and require interpretation, that is to say, "Motashaabehaat", have been sent down from on high with a comprehensive, universal, global, and all - inclusive point of view. Deep down, all the Quranic verses, whether those which are called "motashaabeh" or those which are called "mohkamaat" do enjoy the factor of comprehensiveness in them. Deciphering the Holy Quran would be a different discussion which is raised in the heart of "mohkam" and "motashaabeh" discussion. A translation of the Holy Quran would not be the sane as the original text of the Holy Quran. In order to interpret the Holy Quran, one has to know the Arabic language completely. No translation of the Holy Quran is compared to the original text of the Holy Quran. For instance, if the Quranic translator presents a word - for - word translation of the Holy Quran, it will be completely different from a Quranic interpreter's free translation. Similarly, if a Quranic interpreter wishes to interpret the Islamic orders from the Holy Quran, he or she has to analyze the Quranic text to give a good appropriate meaning. To translate and to interpret the Holy Quran, one has to be versed in the Farsi as well as the Arabic languages. Furthermore, if someone wishes to interpret the Holy Quran using its translated text, it would be a problem and would be difficult for him or her if they do not have a full command of the source language and the target language.

The comprehensive interpretation of the Holy Quran has got a logical condition, that is to say, the contrasting Quranic verse is not supposed to confirm its counterpart. This logical condition is also true for Islamic hadiths; why, because the truth is always fixed and unchangeable. In other words, the truth would not be changeable or uncertain; what is correct is always correct; it cannot be both correct and false at the same time. Some times, it happens that a person allows him or herself to state a question which, from a rational point of view, the wisdom considers it as false. In this case, the person believes that his or her wisdom says something, and his or her heart says a different thing. These persons believe that the wisdom and the heart do not overlap at all. This would be the view of most sufi mystics. Then, they would come to this conclusion that they have to abandon their wisdom, and they have to stick to their heart to reach God, the Almighty, for instance. In most cases, all sufi mystics obtain this view, which is actually a wrong one. If a Quranic interpreter interprets the Quranic verse from this shallow point of view, this interpretation is surely supposed to violate the truth. There are different means for human beings to discover the truth. That the truth may be partitioned, and the truth must not have its originality would be totally a wrong idea. The human being is not supposed to discover Allah by their heart, and to discover non - Allah by their wisdom, or vice versa. Both the heart and the wisdom have to move in the same direction. If somebody moves in a certain direction with their true heart, he or she will surely reach and discover God, the Almighty. On the contrary, if someone moves in a certain direction with their true wisdom, he or she will definitely reach and discover Allah. Furthermore, if a person moves in a certain direction with their true heart and wisdom together, again, they will assuredly reach and discover God, the Almighty, too. Therefore, the heart and the wisdom must move, hand in hand, in one single direction. The routes for reaching and discovering God, the Almighty may be different, but the result will remain the same. The final goal is one. The route to the final goal is one, too. If the subject or the goal would be one, different routes, in the single direction, would meet one another, and they finally become one. No one has the right to consider or grant a single subject a contradictory result. When a defective, non - comprehensive interpretation of the Holy Quran is carried out, it shows the interpreter's point of view, knowledge, and wisdom are defective and non - comprehensive. In this case, the interpreter's wisdom and heart are not in the same direction; in other words, the interpreter's wisdom proceeds in one direction, and his or her heart proceeds in a different direction. As a matter of fact, to produce a comprehensive interpretation of the Holy Quran, both the wisdom and the heart of the interpreter have to proceed in one single direction. When the interpreter's wisdom concludes that an object is an apple, while his or her heart concludes that the object is a chipped apple, this would be a wrong 
conclusion, because both the apple and the chipped apple are the same apple. Beyond the principle of Quranic interpretation is defining and describing the subject's frameworks and structures, that is to say, the discussion's bases, the discussion's dimensions, and its preliminaries are more important than the interpretation itself. If these structural bases, dimensions, and preliminaries are defined well, , and they are clarified in the best way, then, it is hoped that the Holy Quran will show the way to the people of the world as well as the Islamic society so that the Holy Quran's springs of culture and knowledge will flow and show a new path and style of living for the global society. For this reason, I put emphasis again on those structural frameworks, bases, dimensions and preliminaries which have to be used by the Quranic interpreter. As a matter of fact, the method of the interpretation of the Holy Quran would not be a sequential method; it is a topical method. Why, because, if the Quranic discussions are gathered in a sequential manner, they have to be summed up and concluded verse by verse and topic by topic, and then, in the following Quranic verses to be discussed, they have to be summed up and concluded in a sequential manner, and at last, they must be read out in a comprehensive manner. Otherwise, it will be considered as a mere interpretation in which the interpreter has only summed up some Quranic discussions. The comprehensive interpretation of the Holy Quran is a type of interpretation in which the Quranic discussions are gathered and discussed in a non - sequential manner as well as topic by topic. In addition to looking closely at the previous Quranic interpretation of the past, the interpreter has to have an all - inclusive point of view as a necessary condition, combining them in order to sum up those Quranic discussions. The interpreter has to be watchful and attentive not to apply, say, the narrative approach, the Shiite approach, the Sunni approach, the scientific approach, the rational approach, the mystical approach or the philosophical approach alone. Rather all the existing approaches have to be combined in a comprehensive interpretation of the Holy Quran. This is the process of the comprehensive interpretation of the Holy Quran. The Quranic interpreter must be away from prejudiced thoughts and ideas, which, some prejudiced people impose on the Holy Quran. For this reason, even a person who wishes to embark on translating the Holy Quran into the Farsi language, must have a full command of the Farsi and the Arabic languages as well as having an excellent proficiency in Farsi and Arabic literatures. 


\section{The Nature of the Holy Quran}

The Holy Quran has got an existence which is independent of other existences in the world. By independence it is meant that the Holy Quran do enjoy an existential freedom, that is to say, it is not controlled by other creatures and other existences. The Holy Quran has got the ability to intercede. Intercession is something which Gabriel, an archangel, is not able to do. As a matter of fact, as a sign of submission and consent, Gabriel kneels down in front of the Holy Quran. This dimension has a direct connection with prophetic mission and the religion itself, because, it is said that the Holy Quran would be considered as a divine religion. Every Quranic verse does enjoy these dimensions. Every Quranic verse is considered as a rhymed system. Every Quranic verse has a connection with other Quranic verses. Therefore, the beginning of each Quranic verse is connected with the preceding Quranic verse, and every Islamic hadith may have a connection with each Quranic verse, having its own impact and influence.

\section{The Necessity of the Comprehensive Interpretation of the Holy Quran}

In interpreting the Holy Quran in a comprehensive manner, the interpreter has to study and look at the valuable interpretations of the Holy Quran, or, at least, he or she has to study and look at the most outstanding previous interpretations of the Holy Quran, which have been interpreted with different approaches. If the study of previous outstanding interpretation of the Holy Quran do not suffice, the interpreter has to study and look at all the different interpretations of the Holy Quran with different approaches ever produced. For a Quranic interpretation to be really comprehensive, all the previously produced Quranic interpretations must be studied and looked at together by the interpreter. It is necessary that the past Quranic interpretations written and produced by the interpreters such as Seyyed Qutb, Mohyoddin ibn - e Arabi, Rashidoddin Meibodi, and Khadjeh Abdullah Ansari, along with "the Scaled Interpretation of the Holy Quran" written by Allameh Tabataba'ee and other existing interpretations of the Holy Quran must be all studied and looked at together by the interpreter.

There is no doubt that what has been so far written as the interpretations of the Holy Quran are not considered as really valuable interpretations of the Holy Quran. The comprehensive interpretation of the Holy Quran necessitates and requires that all the Quranic words are included in it.

\section{The Functional Definition of the Comprehensive Interpretation of the Holy Quran}

An interpretation of the Holy Quran, which encompasses all interpretive approaches would be called a comprehensive approach. In the comprehensive interpretation of the Holy Quran, every Quranic verse would be interpreted by all interpretive approaches available. First, the Quranic interpreter has to make use of the revelation. As well as intuition, a real revelation is a revelation which has not been sent down from on high. When the revelation is sent down from on high, it will be available to be used by the interpreter. It is true that the revelation would be specially used and sent down from on high to the divine prophets, but it would not be limited to only the divine prophets. As a matter of fact, the revelation would be sent down from on high to be used by human beings. Therefore, human beings are benefited by the revelation sent down from on high, by which they can analyze the worldly affairs. Second, the Quranic interpreter has to make use of Islamic hadiths which are related to the Quranic verses. Therefore, Islamic hadiths are not limited to the innocent imams, who look at Islamic issues by them. As a matter of fact, Islamic hadiths are to be used by all human beings. Islamic hadith, indeed, would be a means to look at worldly affairs. Third, the Quranic interpreter has to make use of the wisdom, which is shared by all human beings. Fourth, the interpreter has to be equipped with the intuition and finding power, which all faithful people enjoy. These four interpretive factors are available to all human beings to look at all subjects and affairs. As a matter of fact, every faithful person must be equipped with all these four interpretive factors. In short, every Quranic verse has to be discussed and looked at by these four interpretive factors. And, unless these four 
necessary interpretive factors are to be used in interpreting the Holy Quran, any contradictory result will be impossible.

\section{The Status of the Comprehensive Interpretation of the Holy Quran}

As a matter of fact, all the interpreters of the Holy Quran have made great efforts, and have tolerated great difficulties in interpreting the Holy Quran, specially those Quranic interpreters who have introduced and presented complete interpretations of the Holy Quran. These Quranic interpreters have indeed spent the most parts of their precious life to explain and describe the Quranic verses. But, I wish they had not placed themselves in a limited direction, which has been below the dignity of the Holy Quran to be interpreted by only the science of mathematics, for instance. There is no doubt that the whole of the Holy Quran would be all mathematics, all reasoning and intellection and rational orders. As one of the Islamic jurisprudential principles say: "Whatever is confirmed by the wisdom (the reasoning and the intellection), will be confirmed by the canon (the divine law and the religious law); and whatever is confirmed by the divine law, will be confirmed by the reasoning. Indeed, every Quranic verse would be considered as mystical. Every Quranic verse would be explained by Islamic hadiths. Of course, in sciences such as mathematics, which depend on reasoning, the coefficient of the error of a conventional and existential branch - (all the observations of the originality have been observed) - will approximately be equal to zero; but from the philosophical point of view, this coefficient of the error will not be equal to zero. There is a big difference between confirming something completely and not rejecting it all. There is a time when we would say, "Confirm this"; and there is a time when we would say, "Do not reject this". If you would not reject something, it would be like that you confirm it, since another means in the world of being has confirmed it; therefore, if the wisdom (reasoning) presents its reason, it will be acceptable. Even when the wisdom (reasoning) may not present its reason, the reasoning will yield to the intuition, although the wisdom cannot comprehend the intuition with its own means. Rejecting an Islamic issue does not mean that it must be explained by only the science of mathematics, for example, and all the mystical interpretations of the Holy Quran should have been rejected, for the reason that they are not compatible with our principles, while, on the other hand, we have to make our wisdom (reasoning) as much as possible, and if we can not make use of our wisdom (reasoning), other Possible means have to be used for obtaining a good, appropriate result. In addition to these, the Quranic interpreter must not look at the Quranic verses in a disintegrative or analytical manner. The disintegrative point of view would be a special point of view. In this point of view, every Quranic interpreter looks at the Quranic verses from his or her own point of view, defining them. When the Quranic interpreter would make use of all possible existing means or approaches, what will be obtained would be a comprehensive interpretation of the Holy Quran. In other words, the resultant interpretation will become both inclusive and exclusive. By "inclusive", it is meant that the interpretation includes all different approaches. By "exclusive", it is meant that the different approaches applied in the Quranic interpretation do not violate the different principles of the existing sciences. Of course, it is not that all the different approaches applied in the Quranic interpretation will completely fit all the existing sciences. For instance, in the physical world, we see a certain color, say, the blue color. If we enter the purgatory, that blue color as seen in the physical world, will not have an existence any more. Or, to give another example, in the physical world, we see an apple. If we enter the purgatory, that apple will not exist any more. As a matter of fact, that apple will not be supposed to be seen as an apple seen in the physical world; the apple's nature may be under zero. When we speak of the comprehensiveness, we mean that the Quranic interpreter have to apply all the possible existing approaches in his or her interpretation. In addition to this, the Quranic interpreter has to study and look all the Quranic interpretations created before. From "the inclusive" point of view, Allameh Tabataba'ee has tried his best to introduce and present an inclusive interpretation of the Holy Quran. For instance, he has studied and mentioned the Sufi mystics' works in his inclusive interpretation. But, from "the exclusive" point of view, no Quranic interpreter has ever introduced and presented an exclusive interpretation of the Holy Quran. The Quranic interpreter must see, say, the physical apple, the superficial apple, the inner apple, the divine apple, the 
purgatory apple as well as all the principles existing in it. In other words, all the existing approaches must be applied in the interpretation of the Holy Quran, and, then, an inclusive and exclusive definition of the Quranic interpretation must be presented and introduced. The different approaches applied in the comprehensive interpretation of the Holy Quran are not supposed to be completely compatible with different existing sciences. Rather, the exclusive factor would be created when a certain scientific principle would not violate any of the interpretive approaches in the comprehensive interpretation of the Holy Quran, and it is encompassed in one of these scientific principles. Therefore, a complete compatibility is not supposed to occur between the interpretive approaches and scientific principles. In addition to this, the comprehensive interpretation of the Holy Quran must not be contradictory with any different interpretive approaches applied in this type of interpretation. The comprehensive interpretation of the Holy Quran would be expected. to be produced and written in a learned way. For this reason, it would be better to employ the learned men and women who have made great efforts in every scientific discipline. In this phase, there would be no need to be a mystic, scientist, or mathematician, because those learned men have truly made great efforts in their own disciplines. As a matter of fact, a mathematician interpreter will surely increase and exalt the Quranic concepts from his or her mathematical point of view. In each of these sciences, there are certain principles, which only the learned men or the scientists are aware of and comprehend, and this is their specialty to distinguish who makes a mistake in a certain scientific field and who does not.

\section{The Base of the Comprehensive Interpretation of the Holy Quran}

A comprehensive interpretation of the Holy Quran is required to be a complete one, that is to say, it has to look at and regard all the Quranic verses; it has to look at all the Quranic verses analogously; it has to investigate all the Quranic verses topically and comparatively; it has to include all the Islamic hadiths related to a certain Quranic verse; it has to encompass all the existing points of view in the interpretation of the Holy Quran such as the mystical point of view, the scientific point of view, the rational point of view and the like. In other words, all the existence must face the whole existence of the Holy Quran. The heart, the soul, the wisdom, and the thoughts of the Quranic interpreter have to serve and comprehend all the Holy Quran. To fulfill this, a comprehensive interpreter is required to embark on interpreting the Holy Quran, fulfilling this with his or her all - inclusive point of view. As it was mentioned earlier in this research paper, to fulfill a comprehensive point of view, the Quranic interpreter must not limit him or herself to a certain point of view. For instance, the Quranic interpreter must not limit him or herself to the mystical approach, or the narrating approach, or to any other single approach. Even a Quranic interpreter who desires to embark on interpreting the Holy Quran in a comprehensive manner, must not limit him or herself to only Shiite sources. Rather, he or she must refer to other Quranic sources, sources which are existing and available to him or her.

\section{The Critique of the Translation of the Holy Quran}

The comprehensiveness we put emphasis on do concern the words and phrases of the Holy Quran in the Arabic language, a language by which the Holy Quran was sent down from on high to the prophet of Islam, His Holiness Muhammed (Peace Be Upon Him and His Family). This comprehensiveness does not concern any translation of the Holy Quran.

Therefore, an interpreter who wants to embark on interpreting the Holy Quran must relate the Islamic hadiths to the original text of the Holy Quran, no to a translated text of it, because a translation of the Holy Quran is not at all considered as the Ariginal text of the Holy Quran. Yet, any translation of the Holy Quran has to be descriptive and explanatory, which truly describes and explains the concepts of the Quranic verses. If the Quranic interpreter would be sure that the concepts of the Quranic verses are not truly described and explained by a word - for - word translation, he or she would not be permitted to create the translation. This is considered a false translation, a fabrication of lies, and is, therefore, not permitted religiously. Furthermore, introducing and presenting and translating the Holy Quran without considering and presenting 
the original text of the Holy Quran would not be permitted religiously. The Holy Quran would be regarded on the basis of its original text, its original speech, its original literature. The language of the Holy Quran is Arabic, a language which belongs to the Holy Quran, but the language of the Holy Quran does relate only to the Holy Quran itself. The literature applied in the Holy Quran is considered as a miraculous literature. Therefore, no one has the right to produce a Quranic translation in the name of the Holy Quran. This is not permitted religiously. I wish the Islamic Republic of Iran's Islamic scholars had not permitted the translators to translate the Holy Quran without comparing them with the original text of the Holy Quran. Unfortunately, three false translations of the Holy Quran were published after Iran's Islamic revolution, without comparing them with the original text of the Holy Quran. The Holy Quran, as I said before, without referring to its original text would not be considered as a true Quran. Similarly, a non - descriptive translation of the holy Quran, too, would not be considered as the true Quran. A good translation of the Holy Quran would be one which compares it with the original text of the Holy Quran descriptively, mentioning all the Islamic hadiths related to all the Quranic verses, so that if there were difficulty in comprehending the Quranic verses on the part of the readers, the translator, by translating both the Quranic verses rightly as well as the Islamic hadiths related to all the Quranic verses, would be able to explain and describe all the probable vagueness's and ambiguousness's for the readership to comprehend. The Arabic literature and orthography are strange ones. They are not like Faris literature and orthography. The Arabic orthography will be changed by the displacement of a verb, word, phrase, or syntax. It is not like Faris orthography in which a word may have several meanings. Any sentence in the Arabic language has not more than a meaning. Therefore, it is the Quranic interpreter's responsibility to comprehend the unquestionable words of God, the Almighty, and to interpret them in the best possible way. Therefore, if a Quranic translation of the Holy Quran would be presented by a Quranic translator, who includes different personal views of his own in the translation, he or she has indeed committed a sin. If we put an emphasis on the Quranic interpreter's all - inclusive points of view in the comprehensive interpretation of the Holy Quran, it would be for this reason that no views of God, the Almighty must not be hidden from the Quranic interpreter. As Imam Khomeini (Peace Be Upon Him) has repeatedly stated, "I quote these [existing] Quranic interpretations with caution, because I fear that God, the Almighty's will would be beyond what we said and comprehended." Since "mohkamaat" (=those Quranic verses which do not need to be interpreted, since they are clear enough) in "motashaabehaat" (=those Quranic versed which need to be interpreted, since they are not clear enough), and specially in "motashaabehaat", would be the final goal of God, the Almighty's will, which is the divine guidance proper, they must be considered in the interpretation of the Holy Quran. A divine message has been sent down from on high so that God, the Almighty's will, that is to say, the divine guidance, will reach human beings. If man, the divine prophets or other Quranic interpreters are supposed to interfere in, and exert their own personal opinions on the Quranic verses, it will be setting aside the purpose of the divine guidance, and this point must not be forgotten at all. The foregoing point, that is to say, exerting one's own personal opinions on the Quranic verses, would be an important issue, so, if the Quranic interpreter would try not to exert his or her own personal opinions on the Quranic verses, and they would introduce and interpret the words of God, the Almighty as they really are, it will help the readership to comprehend the words of God, the Almighty in the best way. This will specially help English - speaking people, who are interested in studying the Holy Quran in English, to have a better understanding of the Quranic concepts; otherwise, they will have difficulty understanding the Holy Quran. According to history, when the Holy Quran entered Europe through its translated copies, the then priests did not allow the Holy Quran to be read and studied by European people of the time. The then church, then, ordered the translators to translate the Holy Quran word - for - word, which was not indeed the real Quran, and published these shallow translations of the Holy Quran to be used by European readers. As a matter of fact, those shallow translations of the Holy Quran did make the Holy Quran and its concepts useless and valueless. Once, Ayatollah Khamene'ee said to European and North American youth, "O youth! Go and look at the Quranic verses, so that you will find out what the divine Quranic verses, so that you will find out what the divine truth is." As a matter of fact, the divine truth is one. But, 
first, we must investigate what the divine truth is.

Try to discover and know the true words whatever they are. Of Course, this is the minimum thing we could do. There has to be a strong force to give hope to all thinkers, youth, and to all those who are always accustomed to ask questions. Indeed, a thinking brain will ask all the questions, and remove all ambiguities. As an old Persian poem says: "Essentially, the religion of Islam would be faultless/ If there is a fault, it is in our way of being a Muslim." It is a rule of thumb. Human thought is essentially dynamic. Human thought is essentially pure. Human thought is essentially truthful. Human thought is not essentially is prejudiced. And these are so significant. There would be no doubt that to have such a thought, the man's mind must be pure; he or she must not have any prejudices, and if they found that they have made a mistake, they must have the courage to acknowledge their making a mistake, which, indeed, such people are rare in the world. Definitely, a man who is a coward person, and those who fear death and disgracefulness will not be able to have and show such courage, because fearing breaking of the identity of oneself by oneself or others would be greater than the fear of death, being killed, killing, war, darkness, beasts and the like. There is no doubt that coward people are not able to step on this path of courage. 


\section{The Process of the Comprehensive Interpretation of the Holy Quran}

\section{Step one:}

A Quranic interpreter who wishes to embark on interpreting the Holy Quran in a comprehensive mannermust look at Quranic words and phrases in Arabic literature and in encyclopedias. Furthermore, he or she must investigate and search all the words and lexical roots related to these Quranic leey leey words.

\section{Step Two:}

A Quranic interpreter who wishes to embark on interpreting the Holy Quran in a comprehensive manner must look for all the synonyms of the Quranic Keywords.

\section{Step Three}

A Quranic interpreter who wishes to embark on interpreting the Holy Quran in a comprehensive manner must look for and investigate all the Quranic verses related to the Quranic subject he or she is going to survey. In addition to this, he or she must look for all the peripheral words and phrases in the Holy Quran.

\section{Step Four:}

A Quranic interpreter who wishes to embark on interpreting the Holy Quran in a comprehensive manner must look for and designate all the Quranic verses related to the meaning and concept of the subject he or she is working on.

\section{Step Five:}

A Quranic interpreter who wishes to embark on interpreting the Holy Quran in a comprehensive manner must look for and designate all the outstanding previous interpretations of the Holy Quran one by one, and separate all the interpretive approaches applied in these Quranic interpretations.

\section{Step Six:}

A Quranic interpreter who wishes to embark on interpreting the Holy Quran in a comprehensive manner must designate all the limits of all the previously interpreted Quranic verses under consideration, and must gather all the existing sources ever written about them.

\section{Step Seven:}

A Quranic interpreter who wishes to embark on interpreting the Holy Quran in a comprehensive manner must gather all the points ever made on those interpreted Quranic verses, which are related to the subject of their discussions.

\section{Conclusion}

The purpose of this research paper has been to clarify and designate how to present the correct interpretation of the Holy Quran in a comprehensive framework, so that, it is hoped, it may be used by Quranic interpreters in the present century. The religion of Islam has a certain concept saying that whoever wishes to reform and improve the world must reform and improve him or herself first. In other words, the world will not be reformed and improved unless the reformer starts to reform and improve him or herself, first.

As a matter of fact, the divine tradition necessitates that if someone would be able to redeem him or himself, he or she, then, will be able to redeem the world. In other words, the inner achievement and success of the reformer will definitely result the outer achievement and 
success. There is no doubt that the comprehensive interpretation of the Holy Quran will be able to create a social transformation in all the continents of the world in the present century, for, this is the divine tradition. As a matter of fact, God, the Almighty Himself has ordered so. On the other hand, a divine prophet whose prophetic mission would be pure, his prophetic mission will become global. But, a human being who always thoughts about and acts upon his or her carnal desires, his or her inspirations and aspirations would be limited and inhuman. Therefore, the more human beings are unchained from their carnal desires, and, thus, the more they become interested in thinking about and acting upon their spiritual and human desires, the more they may influence their society, and the greater their scope of human influence will become. This would be considered as a principle. It is hoped that we, Mushims, will be able to produced and present a complete comprehensive interpretation of the Holy Quran in the near future. God willing! As a matter of fact, the more the world of being are provided with the great thoughts of great thinkers, the more it will improve and advance to a more desirable state. When the interpretation of the Holy Quran is based on the comprehensive approach, and, the mystical approach, the Shiite approach, the Sunni approach, the rational approach, the scientific approach, and the philosophical approach are studied and looked at by the Quranic interpreter more and more, and, then, they are summed up and combined together, this Quranic interpreter will naturally and definitely have a greater toleration and free thought than the Quranic interpreter who has not carried out these things. It is hoped that this approach for interpreting the Holy Quran, that is to say, the comprehensive approach, will provide all the Quranic interpreters with more toleration and free thoughts, so that they will be able to solve all the existing problems and questions about the Holy Quran. We wholeheartedly seek God, the Almighty's help and mercy, and we did start writing this research paper to present it to the dear readership. It is hoped that God, the Almighty will deal with us with His divine kindness, mercy, and generosity, not with His divine justice, for, we are not able to stand His divine justice. Here, I repeat again that the comprehensive interpretation of the Holy must not be created through an exclusive point of view of the Quranic interpreter who only makes use of the Shiite approach, the Sunni approach, the mystical approach, or the rational approach. These exclusive Quranic interpretations would be arbitrary, that is to say, they are written with the Quranic interpreter's personal and limited point of view. The Holy Quran must be read; it has to be studied closely; the Holy Quran's grammar and lexicon must be attentively paid attention to; the literature, the figurative language, and the eloquent manner, in which it has been written, must be looked at attentively; then, the Quranic interpreter, with all of these factors in mind, must sum these interpretive factors up. If the Quranic interpreter found out that a Quranic verse would be in contrast with an Islamic hadith, he or she must proceed cautiously. As a matter of fact, the Holy Quran would be considered as a divine phenomenon given for safekeeping, which is in the hands of the Quranic interpreter. So, the Quranic interpreter has to be a good and trustable keeper of this divine phenomenon given for safekeeping. It would be better that those translators who embark on translating the Holy Quran to translate the Quranic verses word - for - word, and they should translate the related jurisprudential question(s) as well as mentioning the related Islamic theories in the footnote. Before embarking on interpreting the Holy Quran, the Quranic interpreter must learn the syntax and the inflection, the literary techniques, the figurative language, the eloquent language as well as the semantics of the Holy Quran. The language of the Holy Quran would be a special kind of language. Its language is similar to poetry. In interpreting the Holy Quran, the Quranic interpreter must consider and include the rational approach, the mystical approach, the philosophical approach, the theosophical approach, the Shiite hadiths, the Sunni hadiths, and the like, summing them up. In addition to these, the Quranic interpreter has to be free from any prejudices, and must consider and include the jurisprudential and theosophical principles and groundworks, and they must not stick to one single interpretive approach at all. When embarking on interpreting the Holy Quran in a comprehensive manner, the Quranic interpreter must not limit him or herself to a single interpretive approach, a single jurisprudential principle or groundwork, a single theosophical principle or ground work, a single philosophical source, or a single existing presupposition. With these conditions, the interpretive justice will be done and a fair and complete comprehensive interpretation of the Holy Quran will be produced and presented to all. On the 
other hand, the peripheral, subordinate, or minor aspects of the truth may not be called Islam. The secondary order does not comply with the truth of the real religious order, even if it has been obtained, as philosophers say, accidentally. The truth of the religion of Islam would be knowing the true speech. Essentially, the true speech itself would be the truth of Islam. Therefore, the main principle in the interpretation of the Holy Quran in a comprehensive manner would be just, true, and fair. For these reasons, a Quranic interpreter who wishes to embark on interpreting the Holy Quran in a comprehensive manner, must, in his or her comprehensive interpretation, mention the primary Islamic principles, which may or may not be supported and defended, along with the true Islamic principles. On this basis, the Quranic interpreter's comprehensive interpretation has to be an all - in collusive one, enjoying all the comprehensiveness factors. The Quranic interpreter who wishes to interpret the Holy Quran comprehensively, must be without any presupposition; he or she must not have a one - track mind; he or she must have the ability to sum up his or her all - inclusive interpretive points.

In spite of any interpretive summing up on the part of the Quranic interpreter, the miraculous dimension of the Holy Quran necessitates that there will be a more comprehensive interpretation of the Holy Quran by the next Quranic interpreter later in the future. Nowadays, the internet as well as the cyberspace have come to aid the Quranic interpreters, so the Quranic interpreters do have a wide access to all comprehensive pieces of in formation on the Holy Quran itself as well as other Islamic issues and questions. So, the interpretation of those Quranic interpreters who have access to the internet and the cyberspace would be hundreds of times more valuable and better than those produced and presented in the past.

May God, the Almighty bless you all!

\section{References}

Ghazipour, S. (2019). "A Survey of the Quranic sura 'Al - Hamd' and the Comprehen sive Topical Interpretation of the Holy Quran", Samt Publisher, 45-67.

Hashemian Fard, Z. (2008). "The Comprehensive Interpretive Approach (A Qualitative Approach in the Interpretation of the Holy Quran)"; Political Sciences; Strategic View, Angust and September of 2008, 93 and 94, 127-150.

Karimi, M. (2003). "A Quranic Interpretive Approach Accepted by the Honsehold of the Prophet of Islam (Peace Be Upon Them), Religions, Creeds, Beliefs, and Mysticism"; Ma'refat, Publications, 71, 26-34.

Majlessi, M. B. (1403). "Bahaarol Anvaar" (=The Seas of Light", Al - Vafa Institute, Beirut, 1403 A.D.

Mohyoddin ibn-e A. (1407). "The Interpretation of the Holy Quran", 8 ${ }^{\text {th }}$ century A.D. (Known as "Ibn-e Arabi's Interpretation"), with an introduction by: Mustafa Qalib, 17.

Muhammedi yadk, A. (2011). "Classifying the Shiite Interpretation of the Holy Quran on the Basis of Interpretive Approaches", Seven Skies Journal, spring of 2011, thirteenth year, 49, 49-66.

Mutahhari, S. M. (2006). “Monotheistical worldview”, Samt Publisher, 78-83.

Nassiri, A. (2009). "The Supernatural Nature of the Holy Quran form Imam Khomeini's Point of View".

Nilsaaz, Nosrat., \& Dehqaan, A. (2017). "The Ethimology of the Quranic word 'Hamd' using the Sources of Semitic languages”; 'Quranic Sciences and Islamic Hadiths' Research 
Jourual, spring and summer of 2017, 10, 179-198.

Rezaee, M., \& Nowrouzi Anbarakeh, M. (2019). "The Interpretive Approaches of His Holiness, Imam Sajjad (Peace Be Upon Him), The Ethics; Taha Heritage, spring and summer of 2019, 4, 97-114.

Shari'ati Niasar, Hamid; mentioned Ma'aaref Majiid; "The Interpretive Principles and Approaches of the Holy Quran in the book 'Nahjol Blaqah", Nahjol Balaqah Research Magazine, spring of 2016, vol. 13, (scientific - Research), ISC, P.P. 1-24.

Tajeddin, Sh. (1985). "The Comprehen sive Pieces of Information", 42, Razi Publications, Qom, 1985 A.D.

Zarkashi, Muhammed ibn-e Abdullah. (1411). "Al-Borhaan fi Oloum - el Quran", (=The Reason in Quranic Sciences) Dar - al Fikr Publications, Beirut, 1411 A.D. 